\title{
A Review of Post-Burn Contracture Release Procedures at the National Orthopaedic Hospital, Enugu
}

\author{
Aria $\mathrm{ON}^{1}$, and $\mathrm{Gbeneol} \mathrm{JT}^{2, *}$ \\ ${ }^{1}$ Consultant Plastic Surgeon, Plastic Division, National Orthopaedic Hospital, Enugu, Nigeria \\ ${ }^{2}$ Burns and Plastic Unit, Department of Surgery, Faculty of Clinical Sciences, College of Health Sciences, University of Port Harcourt, Nigeria
}

*Corresponding author: Gbeneol JT, Burns and Plastic Unit, Department of Surgery, Faculty of Clinical Sciences, College of Health Sciences, University of Port Harcourt, Nigeria, Tel: +2348033426025; E-mail: tombari.gbeneol@uniport.edu.ng

Received: 23 Dec, 2020 | Accepted: 11 Jan, 2021 | Published: 19 Jan, 2021

Citation: Aria ON, Gbeneol JT (2021) A Review of Post-Burn Contracture Release Procedures at the National Orthopaedic Hospital, Enugu. Clin Res Open Access 7(1): dx.doi.org/10.16966/2469-6714.162

Copyright: (c) 2021 Aria ON, et al. This is an open-access article distributed under the terms of the Creative Commons Attribution License, which permits unrestricted use, distribution, and reproduction in any medium, provided the original author and source are credited.

\section{Abstract}

Background: Contracture release surgeries are done to correct functional impairment, pain or discomfort, recurrent ulceration and cosmetic challenges associated with contractures across joints and mobile structures such as the eyelids.

Aim: This article aims to review all the surgical procedures for post-burn contracture release, in the National Orthopaedic Hospital Enugu (NOHE).

Method: This is a 5-year retrospective surgery of post burn contracture release carried out in NOHE from January 2013 to December 2017. The data for post- burn contracture surgeries was retrieved from the theatre registers, as well as patients' folders from the medical records department. Ninety-four folders were retrieved from the medical record department.

Results: A total of one hundred and thirty- nine surgical sessions were recorded for these patients. The age range was 2 months to 59 years. The record showed the highest number of post burn contracture release surgeries in ages below 3 years while the least was observed in ages between 41 and 60 years. Gender mostly affected were females (53\%). The burn agent that resulted to most of the injuries was flame (52\%) followed by Scald (32\%). Palmodigital contracture release procedures recorded the highest (30\%), followed by elbow (16\%) and mento-sternal (13\%) contractures.

Conclusion: The choice of contracture release procedures was largely influenced by the contracture location and availability of unaffected adjacent skin. Training on post burn contracture prevention for all tiers of health practitioners must be considered a necessity.

Keywords: Contracture; Release procedure; Orthopaedic hospital; Enugu; Nigeria

\section{Introduction}

Contracture is a clinical term, meaning a decrease in passive range of motion at mobile parts of the body or across joints, which may be the result of excessive fibrosis or due to loss of length in muscle or peri-articular connective tissues (cartilage, capsule and ligaments) with increased stiffness in these structures. They develop when normal elastic connective tissues are replaced with inelastic fibrous tissue [1]. All neurological conditions which involve muscle weakness and spasticity are prone to developing contracture. Contractures are long term complications of poor and prolonged wound healing of skin and tissues across a joint, limiting range of motion and function. Burn survivors are often burdened with long- term complications such as scars and contractures. Post burn contractures are largely preventable, but when they occur, they often result in functional limitation necessitating surgical treatment.

\section{Contractures can occur in different parts of the body}

Hand and wrist contractures are commonly in the form of claw deformities, palmar contracture and web space deformities. Claw deformities often result from contracture of the dorsum of the hand with the typical disposition being that of metacarpophalangeal joint extension, proximal interphalangeal joint and distal interphalangeal joint flexion. The wrist may be flexed or extended depending on the site of the scarring. Web space contracture is a common deformity of the web space following severe burns of the hand. Thickened scar or graft contracture along the dorsal edge of the web can produce dorsal hooding or distal creep. Lack of use of splints to maintain injured fingers in an abducted position, usually results in an adducted position at rest; this will result in the burned web healing with contractures. Palmar contracture, on the other hand, occurs in patients, particularly children who grasp hot object and sustain deep burn injuries. It is also seen in children with seizure disorders who have sustained burns.

Contracture of the neck also known as mento-sternal contracture is commonly associated with burns of the head, neck and anterior chest wall [2]. It limits the full range of neck flexion and extension thereby posing the challenge of difficult intubation during post-burn contracture release procedures [3]. In some cases, airway access procedures such as tracheostomy are required for airway control for surgeries carried out under general anaesthesia [3]. Neck contracture has been classified by Achuauer BM [4] into mild, moderate, 
extensive, and severe depending on what fraction of the anterior part of the neck is involved in the contracting band. Contracture of the neck has also been classified by other authors into Type 1 to Type 4 neck contractures [2].

Ankle contractures range in severity and may significantly impact the patient's range of motion and ambulation. Dorsal contractures are the most commonly seen, and they are treated via scar release and soft tissue coverage [5]. Deformities of the foot and ankle depend on the extent of the initial burn. For instance, the scarring and contractural deformities of the toes and the ankle joint are minimal if the burn depth is superficial. The contractural problems more commonly seen in individuals with extensive burns have been traditionally managed with the skin grafting technique and splinting and physiotherapy, which form essential components of the therapeutic reconstruction regimen of burn foot deformities.

This article aims at analyzing all procedures adopted for post-burn contracture release, in the National Orthopaedic Hospital Enugu (NOHE).

\section{Materials and Methods}

This is a 5-year retrospective surgery of post burn contracture release carried out in NOHE from January 2013 to December 2017.

The data for post-burn contracture surgeries was retrieved from the theatre registers, as well as patients' folders from the medical records department. Ninety-four patient records were retrieved from the medical record department. A total of one hundred and thirty- nine surgical sessions were recorded for these patients. The age range was 2 months to 59 years. There was no standardized record of the degree of deformities in these patients across the various anatomical locations of the contractures. The records show that splints were applied over all the areas resurfaced with skin grafts alone after contracture release, in order to prevent re-contracture.

\section{Results}

A table of age distribution, frequency and percentage was prepared from the data as shown in table 1 below. The record showed the highest number of post burn contracture release surgeries in ages below 3 years while the least was observed in ages between 41 and 60 years. The gender mostly affected were females (53\%) as shown in the pie chart (Figure 1).

The burn agent that resulted to most of the injuries was flame (52\%), followed by Scald (32\%) as shown in table 2. The duration of burn to presentation in the hospital was observed most from two months to one year (Table 3 ).

Table 1: Age distribution, frequency and percentage distribution of post burn contracture release record in NOHE.

\begin{tabular}{|c|c|c|}
\hline Age distribution (Years) & Number & Percentage (\%) \\
\hline$<3$ & 29 & 31 \\
\hline $3-10$ & 19 & 20 \\
\hline $11-20$ & 21 & 22 \\
\hline $21-30$ & 8 & 9 \\
\hline $31-40$ & 9 & 10 \\
\hline $41-50$ & 4 & 4 \\
\hline $51-60$ & 4 & 4 \\
\hline Total & $\mathbf{9 4}$ & $\mathbf{1 0 0}$ \\
\hline
\end{tabular}

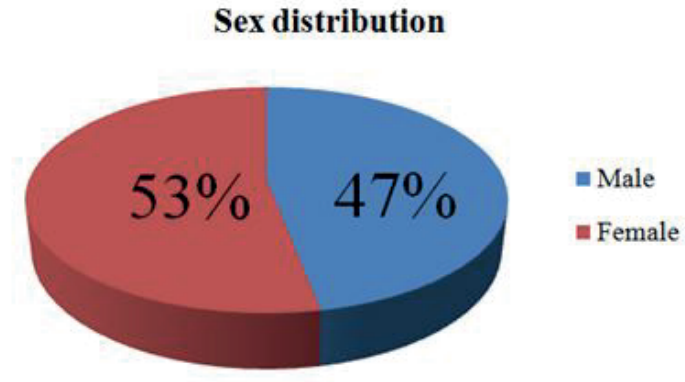

Figure 1: Pie chart showing sex distribution of post burn contracture release surgeries in NOHE.

Table 2: Percentage distribution of burn agent.

\begin{tabular}{|l|c|c|}
\hline \multicolumn{1}{|c|}{ Burn Agent } & Number & Percentage (\%) \\
\hline Flame & 49 & 52 \\
\hline Scald & 30 & 32 \\
\hline Chemical & 6 & 7 \\
\hline Others & 5 & 5 \\
\hline Not documented & 4 & 4 \\
\hline Total & $\mathbf{9 4}$ & $\mathbf{1 0 0}$ \\
\hline
\end{tabular}

Table 3: Percentage distribution of duration of burn to presentation.

\begin{tabular}{|l|c|c|}
\hline Duration from burn to presentation & Number & Percentage (\%) \\
\hline < 2 weeks & 6 & 6 \\
\hline 2 weeks-2 months & 8 & 8 \\
\hline > $\mathbf{2}$ months-1 year & 56 & 60 \\
\hline > 1 year & 24 & 26 \\
\hline Total & $\mathbf{9 4}$ & $\mathbf{1 0 0}$ \\
\hline
\end{tabular}

Palmo-digital contracture occurred mostly as an isolated contracture site in the presentation pattern with a record of $33 \%$ (Table 4). Contractures in multiple sites were observed more in upper limb $(20 \%)$ as presentation pattern. Other regions with contractures had similar presentation pattern with the upper limb.

Palmo-digital contracture release procedures carried out within the period under consideration recorded the highest percentage frequency (30\%). This was followed by elbow (16\%) and mento-sternal (13\%) contractures, as shown in table 5.

\section{Discussion}

Wound healing and the rate of formation of scars have been found to be affected by age. Injuries or wound sustained intra-uterine seem to regenerate new tissue and heal without scar formation, whereas wounds sustained by adults tend to heal imperfectly with the formation of scars and possibly leading to contractures which have aesthetic and functional deformation [6,7]. This is not far from the fact that the processes of regeneration of original tissue outside a safe environment can be highly challenging with the constant fight against infection by viruses and bacteria.

Contractures are better prevented than treated, hence the need to promptly commence preventive strategies such as early wound cover, splinting, scar massage, infection prevention and good pain control. 
Table 4: Percentage distribution of presentation patterns.

\begin{tabular}{|l|c|c|}
\hline \multicolumn{1}{|c|}{ Presentation Patterns } & & \\
\hline Isolated Contractures & Number & Percentage (\%) \\
\hline Palmodigital & 31 & 33 \\
\hline Elbow & 4 & 5 \\
\hline Popliteal & 3 & 3 \\
\hline Microstomia & 2 & 2 \\
\hline Mentosternal & 2 & 2 \\
\hline Axillary & 2 & 2 \\
\hline Ankle/foot & 2 & 2 \\
\hline Subtotal & $\mathbf{4 6}$ & $\mathbf{4 9}$ \\
\hline Contactures in Multiple Sites & & \\
\hline Head and neck region & 7 & 8 \\
\hline Upper limb & 19 & 20 \\
\hline Lower limb & 3 & 3 \\
\hline Contactures across several regions & 19 & 20 \\
\hline Subtotal & 48 & 51 \\
\hline Total & $\mathbf{9 4}$ & 100 \\
\hline
\end{tabular}

Contracture release surgeries are indicated when contractures impair function, or are associated with pain, discomfort or recurrent ulceration. Contractures which occur over vital areas such as the eyelids, the lips, the mento-sternal areas require early surgical correction for functional purposes as well as to prevent further complications such as exposure keratitis associated with post burn contractures of the eyelids. The particular procedure selected for contracture release is dependent on factors such as the anatomical location of the contracture, the size of the contracture, the availability of mobile adjacent skin and soft tissue and the functionality of the particular area. The various options of contracture release procedures (Table 5) such as local flaps and skin grafting can be used singly or in combination, depending on the extent of contracture and the mobility of the adjacent soft tissues.

In this study, $65 \%$ of the procedures involved skin grafting, while local flaps were used in $30 \%$. This is similar to a study by Iwuagwu FC, et al. [8], with $63 \%$ skin grafting and $26 \%$ local flaps. This is also in keeping with Ademola SA study [9], where he posited that skin grafting is used very frequently after release of contracture and is probably the commonest method of closure employed in Nigeria. For effective skin grafting, the healing process of the graft must ensure adequate graft adherence to the bed, promote graft vascularisation and subsequently, manage graft contraction adequately to prevent recurrence of contracture [10-12].

Abdomino-hypogastric flaps were also used for post-burn hand reconstruction. Lateral Superior Genicular flap (LSG) was used in popliteal contracture release procedures. Al Moktader MABD, et al. [13], also used the LSG flap for reconstruction of post burn contractures around the knee with excellent result without necrosis.

Contractures affecting the palmo-digital region were the most frequent presentation amongst patients in NOHE (33\%) as presented in figure $2 \mathrm{~A}$ and $2 \mathrm{~B}$. This appears to be one of the regions of the body where burn injuries occur mostly in patients, particularly children who grasp hot objects. It is also seen in children with seizure disorders who have sustained burns. Contracture release usually involves the excision of scar tissue, leaving a defect which is covered with a skin graft or a flap. Full thickness graft has been reported to be a better option of cover than split thickness graft, as they contract less and

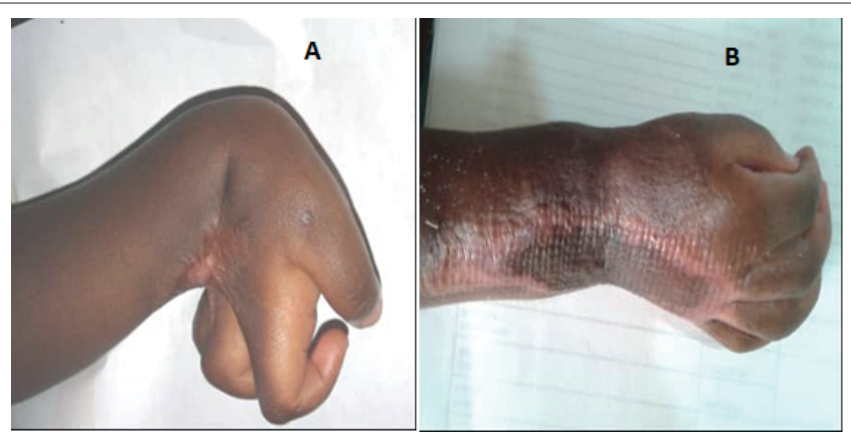

Figure 2: Wrist contracture $(A)$ and release (B).

reduce the risk of contracture recurrence [14-16]. However, the use of full thickness graft is limited to small-sized defects due to the relatively small body surface area available for full thickness harvest.

Patients aged 20 years or younger accounted for $73 \%$ of those who had surgery for post-burn contracture, which shows that the majority of patients suffering from post-burn functional and physical limitations are at a young age. Buchan AC [17] and Iregbulem LM [18] reported the differential growth rate between the burn scar and the adjacent normal tissue. Almost half of the patients reviewed had their acute burn care at private hospitals. About $8 \%$ of patients had their acute burn care managed in our hospital, another $8 \%$ initially received burn care at other tertiary health facilities. This suggests that preventive strategies were either not instituted or ineffective in preventing postburn contractures in more than half of the study participants, despite having their acute burn care in a hospital.

Several factors affect contracture formation. These include age, depth of the burn injury, pain control, infection, early burn wound excision and cover, physiotherapy, anti-contracture positioning and splinting.

There are significant changes in the skin with aging which are responsible for the greater percent of deep burns in the elderly, even after scalds, compared to a younger patient [19-21]. Regeneration is faster in young patient than elderly because of the presence of stem cells that can produce stable cells as replacement for the lost cells. In addition, deep dermal and full thickness burn injuries have a higher likelihood to result to contracture formation than superficial dermal burn injuries [22]. This is because of contraction from the edges of deep partial and full thickness burn wounds.

Pain control and infection prevention also have major roles to play in the ideal management of the burn injured patient. The burn injured patient should be kept as pain free as possible to achieve better healing and encourage compliance to anti-contracture positioning and to physiotherapy [23]. Infection has profound effects on tissue repair, surprisingly; infection does not always lead to impaired healing. Studies have shown that contaminating a wound with bacteria does lead to impaired tissue repair [24-26]. Other reports have also shown that in some cases contaminated wound can improve tissue repair [2729]. It appears that if minor contamination occurs, then inflammation is augmented and the result is improved healing.

Similarly, report by Gore WL, et al. [30], early closure of burn wounds by excising the burned tissues and promptly covering it with skingrafts or its substitutes within first 'five' post-burns day is the standard of care today [31,32]. In addition to improvement in the prognosis, early excision and grafting procedures have been shown to decrease 
Table 5: Percentage distribution of contracture release procedures.

\begin{tabular}{|c|c|c|c|c|c|c|c|}
\hline \multicolumn{8}{|c|}{ Contracture Release Procedures } \\
\hline Contracture & Skin Grafting & Local flaps and alphabet plasty & Regional flaps & Distant flaps & Tissue expansion & Total & Percentage (\%) \\
\hline Ectropion & 10 & & & & & 10 & 8 \\
\hline Microstomia & & 4 & & & & 4 & 3 \\
\hline Mentosternal & 10 & 6 & & & 1 & 17 & 13 \\
\hline Axillary & 5 & 11 & & & & 16 & 12 \\
\hline Elbow & 10 & 11 & & & & 21 & 16 \\
\hline Wrist & 8 & & & & & 8 & 6 \\
\hline Palmodigital & 32 & 4 & & 4 & & 40 & 30 \\
\hline Popliteal & 3 & 3 & 1 & & & 7 & 5 \\
\hline Ankle/foot & 8 & 1 & & & & 9 & 7 \\
\hline Total & 86 & 40 & 1 & 4 & 1 & 132 & \\
\hline Percentage (\%) & 65 & 30 & $<1$ & 3 & $<1$ & & 100 \\
\hline
\end{tabular}

the duration of hospitalization, incidence of metabolic complications, blood transfusion requirements, burn wound contamination, post burn contractures and cost of burn treatment [33-36].

Lastly, range of motion exercises should be commenced early for patients with burn injury to prevent contractures and joint stiffness. This may be suspended temporarily at the immediate post operative period to prevent graft dislodgement or excessive tension on flaps during exercises. The exercises are then resumed after sufficient graft take and consolidation, or after the flap edges have healed [37].

\section{Conclusion}

Contracture release procedures are largely influenced by the contracture location and availability of unaffected adjacent skin. Postburn contractures often require surgical treatment, which may be multiple. Satisfactory outcome was recorded for most of our patients; however, the burden of surgery and possible donor site morbidity cannot be trivialized. Thus, early and active prevention measures should be instituted, as well as training on post burn contracture prevention for all tiers of health practitioners.

\section{Funding}

None

\section{Conflict of Interest}

None declared

\section{Ethical Approval}

Not required

\section{Acknowledgement}

My sincere gratitude to the Department of Surgery, National Orthopaedic Hospital, Enugu.

\section{References}

1. Wade SG, Reenie E (2007) Contractures. In: Kauffman TL, Barr JO, Moran ML (eds) Geriatric rehabilitation Manual. $2^{\text {nd }}$ Edition, Churchill Livingstone Elsevier, Switzerland 115-118.

2. Onah II (2005) A classification system for postburn mentosternal contractures. Arch Surg 140: 671-675.
3. MacLennan SE, Corcoran JF, Neale HW (2000) Tissue expansion in head and neck burn reconstruction. Clin Plast Surg 27: 121-132.

4. Achauer BM (1991) Neck reconstruction. In: Achauer BM (eds) Burn Reconstruction. Thieme Medical Publishers, New York 79-86.

5. Chiou GJ, Puri V, Davis DJ (2019) Foot burn reconstruction. In: Chang J (eds) Global reconstructive surgery. $1^{\text {st }}$ Edition, Elsevier 285-297.

6. Mast BA, Nelson JM, Krummel TM (1992) Tissue repair in the Mammalian Fetus. In: Diegelmann RF, Cohen IK, Lindblad WJ (eds) Wound Healing: Biochemical and Clinical Aspect. WB Saunders Company, United Kingdom 326-343.

7. Boyce ST, Kagan RJ, Yakuboff KP, Meyer NA, Rieman MT, et al. (2002) Cultured skin substitutes reduce donor skin harvesting for closure of excised, full-thickness burns. Ann Surg 235: 269-279.

8. Iwuagwu FC, Wilson D, Bailie $F$ (1999) The use of skin grafts in postburn contracture release: A 10-year review. Plast Reconstr Surg 103: 1198-1204.

9. Ademola SA (2003) Release of contractures. In: Oluwatosin OM (eds) Methods of repair. $4^{\text {th }}$ Edition, Shalom Productions, Nigeria 80-94.

10. Kelton PL (1992) Skin Grafts. Selective Readings in Plastic Surgery 7: $1-25$.

11. Tanner JC, Vandeput J, Olley JF (1964) The mesh skin graft. Plast Reconstr Surg 34: 287-292.

12. Nanchahal J (1989) Stretching skin to the limit: A novel technique for split skin graft expansion. Br J Plast Surg 42: 88-91.

13. Al Moktader MABD, Hassan M, Taman E, Taha A, Elawa S (2010) Lateral superior genicular flap for reconstruction around the knee. Egypt J Plast Reconstr Surg 34: 223-226.

14. Robson MC, Barnett RA, Leitch IOW, Hayward PH (1992) Prevention and treatment of post burn scars and contracture. World J Surg 16: 87-96.

15. Tanzer RC (1948) Correction of interdigital burn contractures of the hand. Plast Reconstr Surg 3: 434-438.

16. Herndon DN (1996) Total burn care. WB Saunders, United Kingdom 485-498.

17. Buchan AC (1971) Deep burns-burn contracture. Hand 3: 90-96. 
18. Iregbulem LM (1980) Post burn volar digital contractures in nigerians. Hand 12: 54-61.

19. Goodson WH, Hunt TK (1979) Wound healing and aging. J Invest Dermatol 73: 88-91.

20. Jacobsen RG, Flowers FP (1996) Skin changes with aging and disease. Wound Rep Reg 4: 311-315.

21. Walter JM, Maibach $\mathrm{HI}$ (2005) Age and skin structure and function, a quantitative approach: Blood flow pH, thickness and ultrasound echogenicity. Skin Res Technol 11: 221-235.

22. Tan J, Chen J, Zhou J, Song H, Deng H, et al. (2019) Joint contractures in severe burn patients with early rehabilitation intervention in one of the largest burn intensive care unit in China: a descriptive analysis. Burns Trauma 7: 17.

23. Griggs C, Goverman J, Bittner E, Levi B (2017) Sedation and pain management in burn patients. Clin Plast Surg 44: 535-540.

24. Smith M, Enquist IF (1967) A quantitative study of impaired healing resulting from infection. Surg Gynecol Obstet 125: 965-973.

25. Irvin TT (1976) Collagen metabolism in infected colonic anastomoses. Surg Gynecol Obstet 143: 220-224.

26. Bucknall TE (1980) The effect of local infection upon wound healing. Br J Surg 67: 851-855.

27. Tenorio A, Jindrak K, Weiner M, Enquist IF (1976) Accelerated healing in infected wounds. Surg Gynecol Obstet 142: 537-543.

28. Raju DR, Jindrak K, Weiner M, Enquist IF (1977) A study of the critical bacterial inoculum to cause a stimulus to wound healing. Surg Gynecol Obstet 144: 347-350.
29. Levenson SM, Kan-Gruber D, Gruber C, Molnar J, Seifter E (1983) Wound healing accelerated by Staphlococcus aureus. Arch Surg 118: 310-320.

30. Gore WL, Widiger TA (2013) The DSM-5 dimensional trait model and five-factor models of general personality. J Abnorm Psychol 122: 816-821.

31. Chamania S, Patidar GP, Dembani B, Baxi M (1998) A retrospective analysis of early excision and skin grafting from 1993-1995. Burns 24: $177-80$.

32. Prasanna M, Mishra P, Thomas C (2004) Delayed primary closure of the burn wounds. Burns 30: 169-175.

33. Kisslaogglu E, Yuksel F, Uccar C, Karacaogglu E (1997) Rationale for early tangential excision and grafting in burn patients. Acta Chir Plast 39: 9-12.

34. Pietsch JB, Netscher DT, Nagaraj HS, Groff DB (1985) Early excision of major burns in children: effect on morbidity and mortality. J Pediatr Surg 20: 754-757.

35. Heimbach DM (1987) Early burn excision and grafting. Surg Clin North Am 67: 93-107.

36. Still JM Jr, Law EJ (2000) Primary excision of the burn wound. Clin Plast Surg 27: 23-47.

37. Goel A, Shrivastava P (2010) Post-burn scars and scar contractures. Indian J Plast Surg 43: S63-S71. 